\title{
Investment in Agriculture and Extractive Industry: A Panacea for National Development
}

\author{
Cordelia Onyinyechi Omodero ${ }^{1} \&$ Kabiru Isa Dandago ${ }^{2}$ \\ ${ }^{1}$ Department of Accounting, Faculty of Social \& Management Sciences, Clifford University Owerrinta, Abia State, \\ Nigeria \\ ${ }^{2}$ Department of Accounting, Faculty of Social \& Management Sciences, Bayero University, Kano, Nigeria \\ Correspondence: Cordelia Onyinyechi Omodero, Department of Accounting, Faculty of Social \& Management \\ Sciences, Clifford University Owerrinta, Abia State, Nigeria.
}

Received: October 3, 2019

Accepted: January 15, 2020

Online Published: March 5, 2020

doi:10.5430/rwe.v11n1p34

URL: https://doi.org/10.5430/rwe.v11n1p34

\begin{abstract}
Economic diversification into agriculture and extractive industry in Nigeria has been a fascinating and crucial economic issue that deserves consideration especially as the country is shifting from mono-economy (caused by oil boom) to other viable economic sectors. The global economic meltdown and depression have stimulated countries to look into other sectors of the economy in order to enhance their national development. Hence, this study tries to examine the contribution of agriculture and extractive industry to the Nigeria's real gross domestic product (RGDP). The study makes use of time series data gathered from CBN Statistical Bulletin ranging from 1981-2017 and employs Ordinary Least Squares (OLS) method as the statistical tool with the aid of e-views version 9. The findings reveal that agriculture has a robust and noteworthy positive impact on RGDP while the solid mineral equally has a substantial positive influence on RGDP. However, crude petroleum (proxy for crude petroleum \& natural gas) has a positive inconsequential effect on RGDP. This brings the study to a conclusion that investment in agriculture and solid minerals is highly imperative at the moment. Therefore, the study has suggested that economic diversification should be focused more on agriculture and solid mineral extraction. In addition, the government should try to manage the crude petroleum and natural gas exploration so as to prevent fund repatriation and transfer to other countries due to borrowed technology.
\end{abstract}

Keywords: agriculture, extractive industry, crude petroleum and natural gas, investment, national development, solid minerals

JEL Classification Codes: E01, E62, L71, L72, O13

\section{Introduction}

Economic diversification in Nigeria has been a topical issue, more especially as Nigeria is seen to be having a mono-economy due to over dependence on oil revenue which has actually limited investment in other sectors of the economy. Everyone in the country is concerned about the survival of the nation which could only be possible by exploiting investment opportunities in the agricultural and extractive industries mainly, as it has to do with farming, fishery, solid mineral extraction, coal mining and other mining. However, the contribution of agriculture and extractive industries to a nation's gross domestic product (GDP) cannot be overemphasized. They play the role of accelerating the growth of gross domestic product (GDP) and enabling the overall economic development by generating employment and revenue, assuring independence in food production and security, supplying tools to other fields and foreign exchange earnings (Lawrence \& Salako, 2015).

In the early 1990s, the value of world's industrial sector had a sharp increase. For example, over (60\%) of the rise could be credited to six major industrial countries - the US, Japan, Germany, Italy, the UK and France. While developing nations included $21 \%$ of manufacturing vale rise. This connotes that there is an apparent gap between developed and developing countries, as examined by (Kniivilä, 2004).

There is no doubt that Nigeria is blessed with abundant natural resources and fertile lands. It is therefore, unfortunate that two out of every three Nigerians live below the poverty line of \$1 per day in income (World Bank, 2012) despite the natural resource endowments and the green nature of the nation. Nigeria is naturally gifted with an abundant 
fertile soil and suitable climate for agriculture. Though, $75 \%$ of its land is suitable for farming, but only $40 \%$ has been cultivated (Omorogiuwa, Zivkovic \& Ademoh, 2014). The challenges facing agriculture in Nigeria range from poor access to credit facilities, lack of infrastructure and larger markets, environmental pollution and degradation, research and extension of services (Olajide, Akinlabi and Tijani, 2012). These barriers have actually been the major constraints affecting agricultural contributions to the national development.

Over the years, the extractive industry activities in Nigeria have been concentrated on crude petroleum and natural gas, while solid minerals such as coal mining, metal ores, quarrying and other mining have been on a low scale. However, investment in extraction of solid minerals and agriculture could have long been a tool to national development, but has been neglected over the years. Currently, the Nigerian Stock Exchange only has five (5) listed companies (Ellah Lakes Plc., FTN Cocoa Processors Plc., Livestock Feeds Plc., Okomu Oil Palm Plc., and Presco Plc.) in agricultural industry and four (4) quoted companies (Aluminium Extrusion Ind. Plc., B.O.C. Gases Plc., Multiverse Mining and Exploration Plc., and Thomas Wyatt Nig. Plc.) in Natural Resources or extractive industry. This number is practically insufficient and inadequate for national development in a well-endowed nation such as Nigeria. This simply connotes that the rest of the businesses in this category are either underground businesses (Omodero, 2019) or do not have the needed financial support from the authorities to expand these businesses that are economically capable of contributing meaningfully to the national development.

Nigeria has really gone a long way in economic distress and poverty due to lack of economic diversification into other areas that could improve the economic situation of the country. The situation has led to massive poverty, unemployment and insurgency in some parts of the country. The contribution of the oil revenue to the national development is highly at the decreasing stage. However, this paper has been targeted to measure the contributions of agriculture and extractive industries to national development. The specific objectives are to evaluate the extent to which agriculture (AGR), solid minerals (SDM), crude petroleum and natural gas (CPG) have contributed to the Real Gross Domestic Product (proxy for national development).

The choice for RGDP in measuring national development is because everything about a nation's economy revolves around the RGDP. That is, all public and private sectors' activities are accounted for under a country's RGDP which is also adjusted for price level changes (inflation or deflation). Therefore, RGDP is designed not only to account for manufacturing, agriculture, aviation, banking industries, etc. but to also capture the income/expenditure of a nation's workforce, health and education sector. These are referred to as the major components of Human Development Index (HDI) (Mahendr, 2018). Thus, the choice of RGDP for national development is justified because it has a broad coverage of all activities in an economy.

\subsection{Hypotheses}

$\mathrm{HO}_{1}$ : Crude petroleum and natural gas (CPG) do not significantly influence the real gross domestic Product (RGDP).

$\mathrm{HO}_{2}$ : Solid minerals (SDM) do not have significant impact on RGDP.

$\mathrm{HO}_{3}$ : Agriculture do not significantly contribution to RGDP. 


\section{Literature Review}

\subsection{Conceptual Framework}

\section{EXPLANATORY VARIABLES}

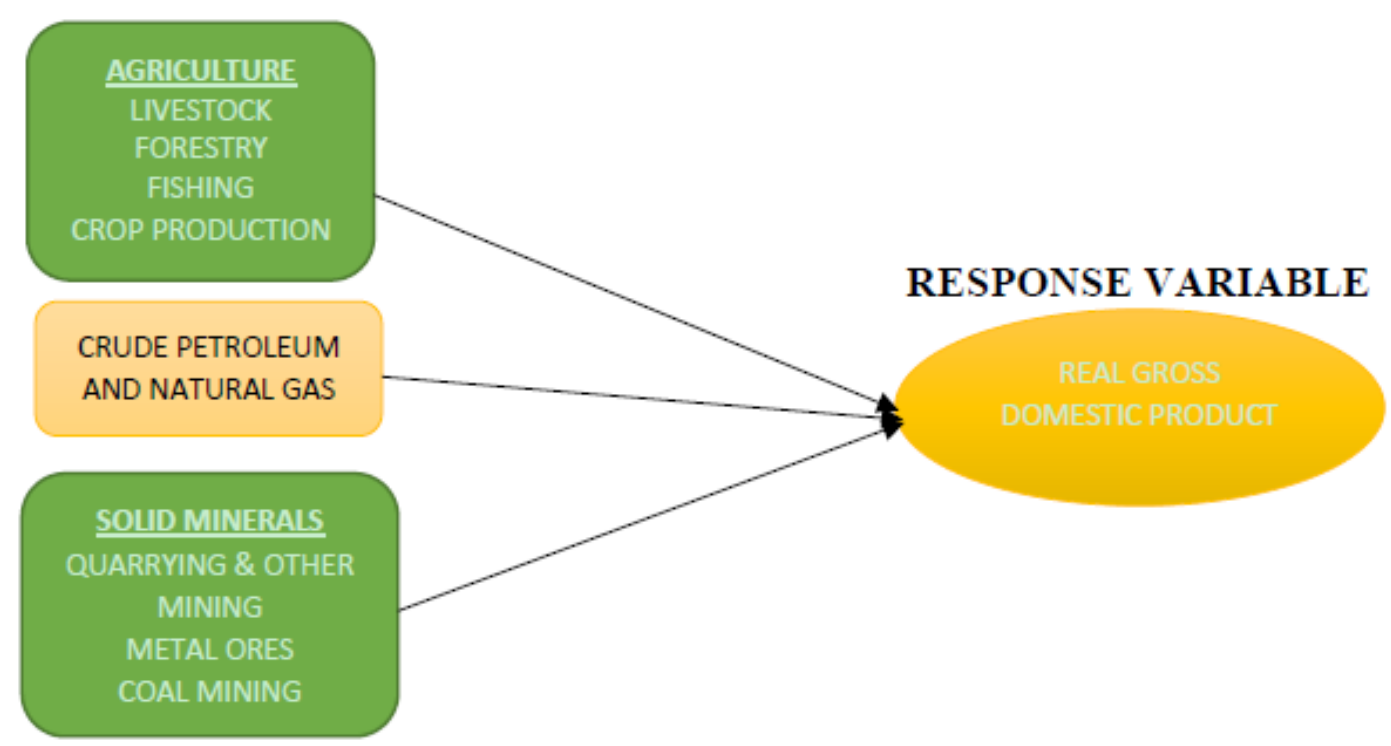

Figure 1. Conceptual framework of agricultural and extractive industry contribution to RGDP

Source: Authors’ Desk Research, 2018.

\subsubsection{Concept of Agriculture and Economic Development}

Agriculture is referred to as the cultivation and production of crop plants and livestock products. It is a very broad term encompassing all aspects of crop production, livestock farming, fisheries, forestry, etc. (My Agriculture Information Bank, 2018). Rimando (2004) defines agriculture as the systematic raising of useful plants and livestock under the management of man. Therefore, it is the activity of man which has to do with production of food, fiber, fuel, etc. by the optimum use of terrestrial resource i.e. Land and water (My Agriculture Information Bank, 2018). Abellanosa and Pava (1987) posit that agriculture is the growing of both plants and animals for human needs. According to Rubenstein (2003), agriculture is the deliberate effort to transform a portion of Earth's surface through the cultivation of crops and the raising of livestock for sustainable or economic gain. Economic development scholars have stressed on how agriculture can suitably contribute to national development and modernization (Olajide et al., 2012). This is why Todaro and Smith (2003) posit that national development and sustainability can only be achieved through advancement in agricultural sector and rural area overhauling through provision of good infrastructures.

Agriculture is synonymous with farming and can be described as the true reflection of a nation's economic strength and development. Besides, it is a process that makes use of all the factors of production (such as land, labor, capital and man) to produce plants, animals, solar energy and forest resources for consumption and providing the agrarian products which is demanded by other fields (Lawrence \& Salako, 2015).

In Nigeria, agriculture includes livestock production, forestry, fishing and crop production (CBN, 2018). About 70\% of the population is engaged in agriculture, therefore, economic development in Nigeria may be difficult to achieve if agriculture sector is not developed (Odetola \& Etumnu, 2013). The role of agriculture to economic development of a country is enormous. According to Pragyandeepa (2018) it includes: contribution to national income, source of food supply, employment opportunities, development of rural areas, creation of larger market for both raw materials and output for industries. It minimizes political and social tension by removing inequality in a country. 


\subsubsection{Concept of Industry and Economic Development}

Industry refers to production of goods and service with regimented plants, using high degree of specialization and automation. It can likewise include other commercial activities that supply goods and services like transportation and hospitality (Verspagen, 2000). In addition, such a sector refers to mining, manufacturing, construction, gas, water and electricity (Sahoo \& Sethi, 2012). The role of Industrialization sector is highly imperative for national development, and for poverty alleviation. However, industrialization arrangement has its effects on how the economy of nations can benefit from growth (Sahoo \& Sethi, 2012). Thus, increasing industrial field is very necessary for economic development (Kniivilä, 2004). Starting with the industrial revolution, technological adjustment has played crucial role in industrial sector (Sahoo \& Sethi, 2012).

\subsubsection{Extractive Industry and Economic Development}

Mineral, oil, and gas extraction are transformative activities. These activities are risky transgression of the order of things, but provide unique avenues to harness the transformative potential of extraction which motivates development processes (Himley, 2015). Any processes that involve the removal of raw materials from the earth to be used by consumers is referred to as extraction. The extractive industry activity consists of any operations that remove metals, minerals and aggregates from the earth. For instance, extraction of oil and gas, mining, dredging and quarrying (Business Dictionary, 2018). In Nigeria extractive industry activities comprise extraction of crude petroleum and natural gas, metal ores, coal mining, quarrying and other mining activities. Manji (2014) noted that Africa as a continent has $10 \%$ of the world's reserves of oil, $40 \%$ of its gold, and nearly $90 \%$ of the chromium and the platinum metal group which are probably yet to be discovered. According to Manji (2014), the natural resource extraction in Africa contributes more than 30\% of its GDP. Therefore, extractive industry activities are needful alteration of the direction of nature which helps to discover and extract hidden treasures (natural resources) deposited in the water, land, forest and mountains for proper national development.

\subsection{Theoretical Review}

The study hinges on the theory of investment and economic growth theory by Adam Smith (1776). The regulatory framework includes: International Reporting Standards (IFRS) 6 and International Accounting Standards (IAS) 41.

\subsubsection{Theory of Investment}

The theory of investment is a body of knowledge that is applied during a decision making process that involve making the right choice among investment options (Younis, Biaban \& Burhan, 2015). This choice making is expedient more especially when finance becomes a limiting factor. It incorporates the capital asset pricing model, efficient market hypothesis, portfolio theory, arbitrage pricing theory, and rational pricing (Eklund, 2013).

Jorgenson and Stephenson (1967) assessed investment theory by using quarterly data on investment expenditures for a whole durable and non-durable manufacturing. They established that based on the neoclassical theory of optimal capital accumulation; investment behavior model reasonably provides explanation for real investment expenditure. Thus, their conclusion suggest that policy instruments, which have a key role in determining investment expenditures involve the tax form and tools that impact the capital cost.

Notwithstanding the market forces, Investments in agriculture and industrial sector are driven by policy changes. To be more explicitly, in several food-importing nations, governments have buttressed investments in agricultural in foreign countries as element of their national food security schemes (Tiffen \& Mortimore, 1990). In addition to political aspects, economic forces arouse more participation of agribusiness in production (Souza \& Paulo, 2014). While in high income nations, Investment in industrial sectors is high; investment in agriculture is recently getting bigger in low and mid income nations (Vermeulen \& Cotula, 2010). This is because of some structural aspects, for instance; Population development, rise in urbanization rate (which explore the contribution of the world's population that relies on buying food) and diet changes (such as increasing demand for fast food and meat in large industrial nations), and therefore, this leads to increasing demand for food (Godfray et al. 2010). Additionally, agriculture increasingly becomes attractive investment option, when demand for agriculture commodities and energy increases worldwide, meanwhile; when technological and industrial capacity for higher products and returns increase (Kniivilä, 2004).

In order to decide whether an investment is to be initiated or not, with the consideration of high degree of profit, there are a number of different decision rules. Such rules commonly consider the future expected cash flow caused by investment, investment cost and capital cost of the company (Love \& Zicchino, 2006). Further, Scheibl \& Wood (2004) conclude that there are four investment objectives, such as: rise in market share, increase the output of exciting capacity, modernize; minimize shareholdings. In addition, Richardson (1960) imposes that the profitability 
of an investment business relies on other firms' investment behavior. Alfredo \& Vicente, (2010) defined investment behavior as how investors work, expect, examine and review the decision making processes, which incorporates the psychology of investment, accumulation of information, comprehending and defining, research and examination. In respect of evaluating an investment opportunity is profitable Richardson (1960) also emphasizes that, free access to information is very important. This information is gained through research and empirical studies.

\subsubsection{Economic Growth Theory}

In the Adam Smith (1776) theory income per capita or GDP is the indicator for the average level of country's prosperity. It is not necessary to consume annual income during the year, but what is not consumed is saved and become other investment or an export surplus. In both uses it adds to the national wealth and thereby becomes a source of future consumption, and then growth (SØrensen \& Whitta-Jacobsen, 2010). In the Fei-Ranis model, technological progress and aggregation of capital are significant in the growth of a country's economy (Souza \& Paulo, 2014).

\subsubsection{International Financial Reporting Standard (IFRS) 6}

IFRS 6 applies to exploration and evaluation of (E\&E) expenditures when the legal rights to explore have been obtained. It specifies that expenditures incurred before an entity obtains the legal right to explore mineral resources have to be generally expensed. IFRS 6 does not apply to expenditures after the technical feasibility and commercial viability of extracting mineral resources are demonstrable. The E\&E expenditures allowed by the standard which can be capitalized include: cost of geological and geophysical studies, the acquisition rights to explore, exploratory drilling, trenching and sampling.

\subsubsection{International Accounting Standard (IAS) 41}

IAS 41 prescribes the accounting treatment and disclosures that relate to agricultural activity. The standard specifies that an entity shall recognize a biological asset or agricultural produce when: the entity controls the asset as a result of past events, it is probable that future economic benefits associated with the asset will flow to the entity, and the fair value or cost of the asset can be measured reliably. Biological asset shall be measured on initial recognition and at the end of each reporting period at its fair value less cost to sell. Except where the fair value cannot be measured reliably. Agricultural produce harvested from an entity's biological assets shall be measured at its fair value less costs to sell at the point of harvest.

\subsection{Empirical Review}

\subsubsection{Agriculture and Economic Development}

Olajide, et al., (2012) examined agriculture resource and economic growth in Nigeria using the Ordinary Least Squares regression method. The problem of the study was the financial and infrastructural constraints agriculture faces in Nigeria which invariably affect its maximum contribution to economic development in the country. The secondary source of data employed ranged from 1970-2010 and were obtained from Central Bank of Nigeria (CBN) Statistical Bulletin, 2010 edition. The dependent variable was the gross domestic product (GDP), while the independent variable was the agricultural output. The regression result revealed that agricultural output had a robust and positive significant influence on the Nigerian economy. The study further revealed that both the $\mathrm{R}$ and $\mathrm{R}^{2}$ were 99\% which showed a high positive relationship with GDP and also suggested that agriculture explained almost 99\% of the variations in the GDP of Nigeria. The study concluded that agriculture is in a better position to enhance national development in Nigeria and should be supported by the government.

Younis, et al., (2015) considered sharing the agriculture and industrial sectors in the economic growth of Iraq using ordinary least squares (OLS) application. The research centered on the great potentials of Iraq as a nation despite the three wars the country experienced which had extensive adverse effect on the economic development. The study employed secondary source of data from 1980 to 2014 and found evidence that both agriculture and industrial sectors had positive impact on the gross domestic product (GDP) of Iraq. Although the contribution of agriculture to the GDP was higher than that of the industry. The study therefore, suggested that agriculture and industry should be encouraged by the government in order to boost economic development in Iraq.

Abula and Mordecai (2016) investigated the impact of agricultural output on economic development in Nigeria using annual time series data ranging from 1986 to 2014. The study made use of per capita income (PCI) as proxy for economic development which is the dependent variable while agricultural output and government spending on agriculture were the independent variables. The findings revealed that agricultural outputs had significant and 
positive impact on PCI. The result of the study simply explained that agriculture plays an important role in the country's national development.

Eze (2017) studied agricultural sector performance and Nigeria's economic growth using Vector Error Correction Model (VECM) and Granger Causality test. The study employed time series data which spanned from 1980 to 2014. The response variable used for the study was the real gross domestic product (RGDP) while the explanatory variables were: value of agricultural output (VAO), foreign private investment (FPI) and financial development (FD). The VECM revealed that VAO contribution to the RGDP was positive but insignificant.

\subsubsection{Solid Minerals and Economic Development}

Jalloh (2013) used panel regressions to examine the impact of natural resources endowment on economic growth in West African Countries. The study employed a Barrow-type growth model, and identified the problem of corruption in the public sector and civil conflicts in West Africa despite their natural resource enriched economies. However, evidence from the panel regression result indicated that natural resource endowments had insignificant positive impact on economic growth in West Africa. Though the study failed to state the period covered by the panel data used, but suggested proper management of natural resource export revenue and policy measures to eradicate the menace of corruption in the public offices.

David, Noah and Agbalajobi (2016) carried out an empirical analysis of the contribution of mining sector to economic development in Nigeria. The sector employed time series data ranging from 1960 to 2012 which were analyzed using Error Correction Model (ECM). Though the data sources were not clearly specified, but the findings revealed that solid minerals had strong and positive impact on economic development in the country.

Olofin and Odeleye (2016) employed annual time series data covering the periods from 1996 to 2014 to investigate the impact of solid minerals and government effectiveness on poverty reduction in Nigeria. All the data were sourced from the World Governance Indicators and CBN Statistical Bulletin (2014). Dynamic Ordinary Least Squares (DOLS) and Fully Modified Ordinary Least Squares (FMOLS) models were used to analyse the impact of various solid minerals and government effectiveness on poverty alleviation in Nigeria. The results indicated that solid minerals such as coal, metaore, quarry and others reduced poverty level but government effectiveness had positive relationship with poverty level in Nigeria.

\subsubsection{Crude Petroleum/Natural Gas and Economic Development}

Torben (2012) studied the economic impact of natural resource endowment on the Norwegian economy. The study was a comparative case study and made use of time series data spanning from 1971 to 2007. The data were sourced from Norway Statistics website and US Energy Information Administration (EIA). The findings of the study revealed that annual GDP per capita of the country increased by $20 \%$ due to the petroleum resources and natural gas in Norway.

Usman, Ikemefuna and Fatimah (2015) assessed the evidence of petroleum resources on Nigerian economic development using time series data which spanned from 2000-2009. The study made use of gross domestic product (GDP) as the response variable and oil revenue as the independent variable. The findings revealed that oil revenue had significant positive influence on the GDP. The recommendation is that the Nigerian government should equip the country with the necessary technology for petroleum exploration which could help in restricting foreigners' involvement.

Nwoba and Abah (2017) examined the impact of crude oil revenue on economic growth in Nigeria with an annual time series data which covered periods from 1960-2010. The problem of the study was the argument that multinational oil companies dominated the oil industry in Nigeria and profits were often repatriated to their home country for expansion while Nigeria was seen to be impoverished and exploited. Using Ordinary Least Squares (OLS) regression analysis, the study however provided evidence that crude oil revenue impacted significantly and positively on gross domestic product (GDP) in Nigeria.

\subsection{Research Gap}

The study is an extension to what other scholars have done based on the above literature review. The gap is that it has extended empirical evidence in this area of study to 2017 since the study covers the period from 1981-2017. The most important gap is the evaluation of the level of contribution of agricultural, solid minerals and crude petroleum and natural gas to determine to RGDP (used as proxy for national development) in one single study. 


\section{Methodology}

The study employed descriptive research design which permits numerical gathering of research data on selected variables for statistical analysis. The annual time series data used spanned from 1981-2017 and were gathered from the Central Bank of Nigeria (CBN) Statistical Bulletin 2017 edition. The data obtained were on RGDP (proxy for national development) and on crude petroleum and natural gas (CPG), solid minerals (SDM) and agriculture (AGR) which are the explanatory variables. The statistical tool used for regression analysis was the Ordinary Least Squares (OLS) method with the aid of E-views Version 9. Augmented Dickey Fuller (ADF) was used to conduct unit root test which helped in establishing stationarity of data to avoid spurious regression result. Johanson Cointegration and Granger causality test were carried out to establish long/short run effects as well as causality effects on the variables. The model specification used in this study, though modified, was adopted from Olajide et al. (2012); Younis, et al. (2015). It is specified as shown below:

$$
\mathrm{RGDP}=\mathrm{f}(\mathrm{CPG}, \mathrm{SDM}, \mathrm{AGR})
$$

This is mathematically stated as follows:

$$
\text { LOGRGDP }=\beta_{0}+\beta_{1} \text { LOGCPG }+\beta_{2} \text { LOGSDM }+\beta_{3} \text { LOGAGR }+\varepsilon
$$

Where:

$\begin{array}{ll}\text { RGDP } & \text {-Real Gross Domestic Product } \\ \text { CPG } & \text {-Crude Petroleum and Natural Gas } \\ \text { SDM } & \text {-Solid Minerals } \\ \text { AGR } & \text {-Agriculture } \\ \varepsilon & \text {-Error term } \\ \beta_{1}-\beta_{3} & \text {-Coefficients of the independent variables. }\end{array}$

\section{A Prior Expectation:}

$\beta_{1}-\beta_{3}>0$

A prior economic expectation is that all the predictor variables (CPG, SDM and AGR) should be greater than zero which implies positive contribution to RGDP.

\section{Results Presentation and Data Analysis}

\subsection{Data Trend}

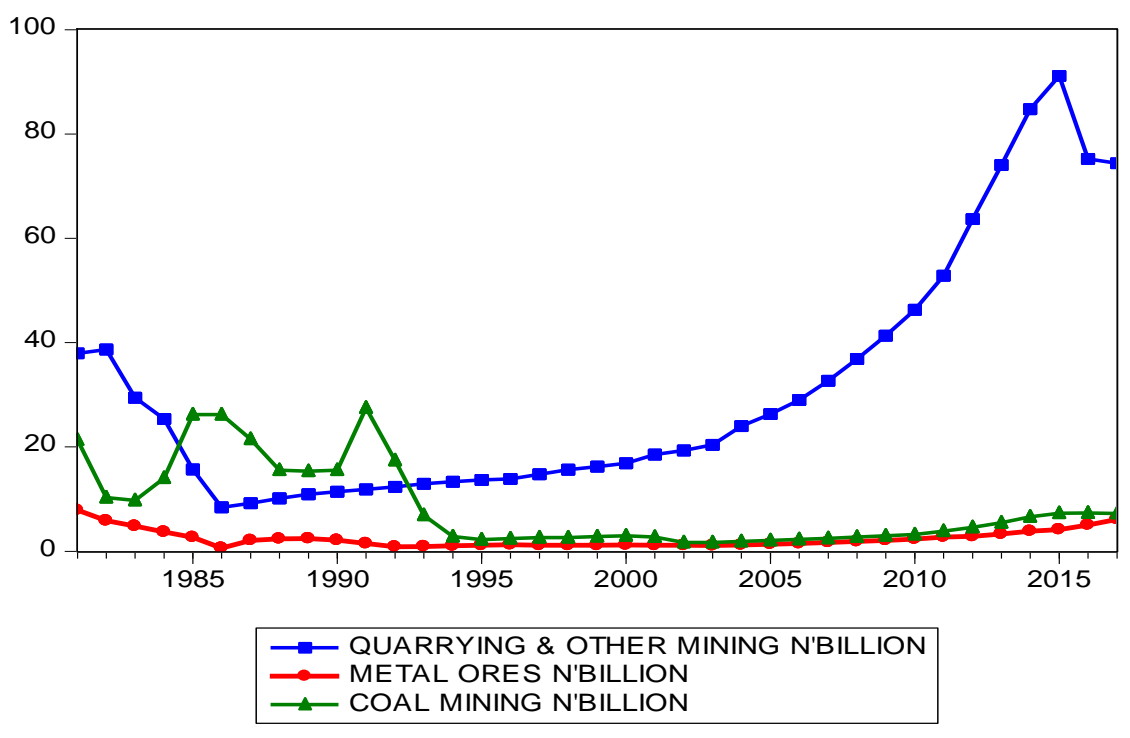

Figure 2. Trend of solid minerals contribution to RGDP in Nigeria from 1981-2017

Source of Data: CBN Statistical Bulletin, 2017 
Figure 2 shows the graphical representation of the components of solid minerals' contribution the RGDP. From the graph, quarrying and other mining came down from 1986 to 1993 but rose above others in the 2000s. Coal mining was rising in the 1980s and 1990s, but decline from 1995 to date. Metal ores is yet to be well harnessed as the graph depicts its low contribution from the onset.

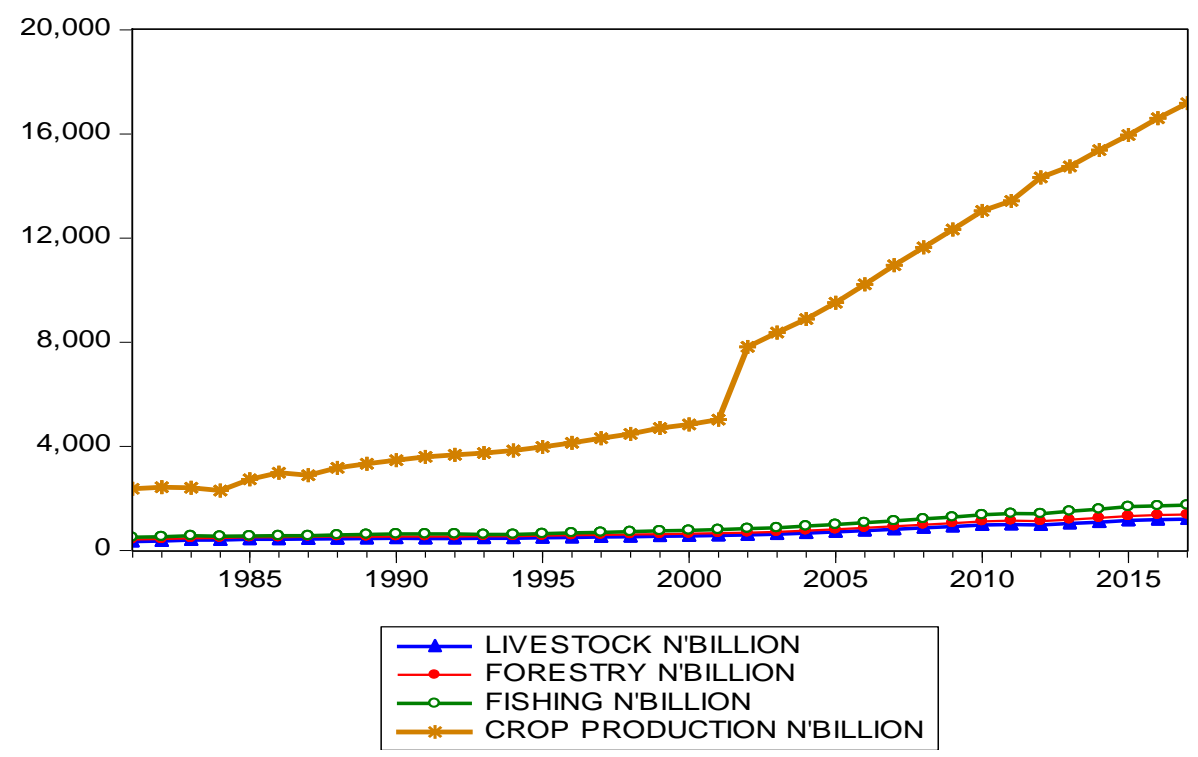

Figure 3. Trend of agriculture contribution to RGDP in Nigeria from 1981-2017

Source of Data: CBN Statistical Bulletin, 2017

From Figure 3 above, crop production seems to have more rapid contribution to RGDP. This could as a result of its popularity in the rural areas of almost all parts of the country. The other agricultural resources are yet to gain stability.

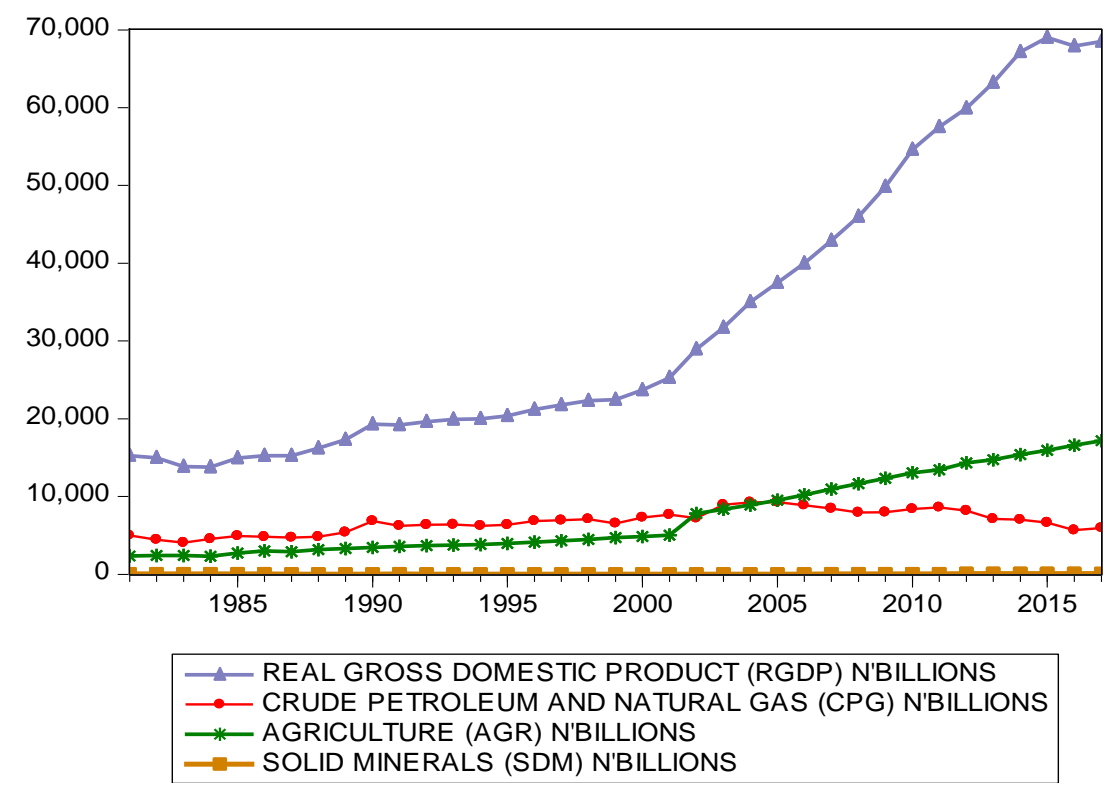

Figure 4. Trend of RGDP, CPG, AGR and SDM from 1981- 2017

Source of Data: CBN Statistical Bulletin, 2017 
Figure 4 depicts that crude petroleum and natural gas contribution to RGDP declined from 2005 to 2017 while agriculture gained more strength in contributing to RGDP. However, Solid Minerals are yet to be exploited as the contribution is not yet visible.

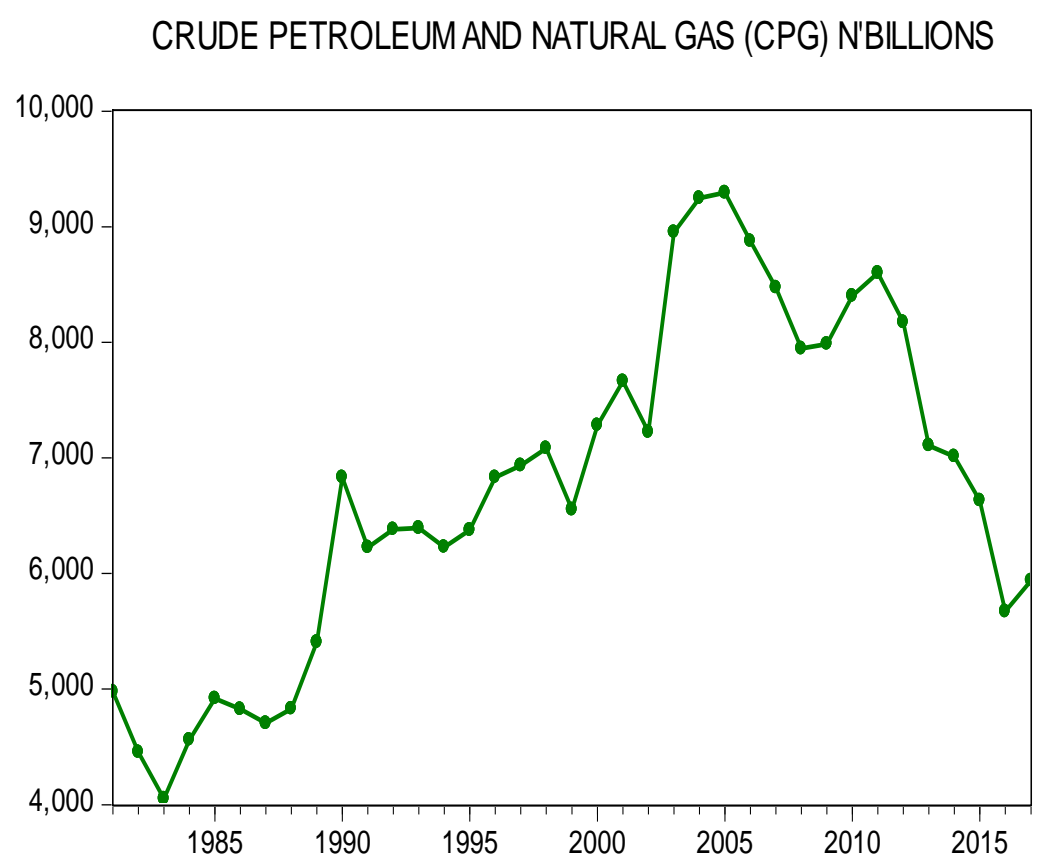

Figure 5. Trend of CPG from 1981-2017

Source of Data: CBN Statistical Bulletin, 2017

From Figure 5, crude petroleum and natural gas got it peak in 2003 and 2004, the decline began from 2005. This shortfall could be as a result of global economic meltdown which actually affected oil prices.

\subsection{Unit Root Test}

Table 1. Summary table

ADF Unit Root Test and Order of Integration

\begin{tabular}{llllll}
\hline VARIABLE & $\begin{array}{l}\text { ADF } \\
\text { T-STATISTICS }\end{array}$ & $\begin{array}{l}\text { MACKINNON } \\
\text { CRITICAL } \\
\text { VALUE AT 5\% }\end{array}$ & P-VALUE & $\begin{array}{l}\text { ORDER OF } \\
\text { INTEGRATION }\end{array}$ & REMARKS \\
\hline RGDP & -3.339751 & -2.948404 & 0.0205 & $\mathrm{I}(1)$ & STATIONARY \\
\hline CPG & -5.521934 & -2.948404 & 0.0001 & $\mathrm{I}(1)$ & STATIONARY \\
\hline SDM & -3.807608 & -2.948404 & 0.0064 & $\mathrm{I}(1)$ & STATIONARY \\
\hline AGR & -5.796345 & -2.948404 & 0.0000 & $\mathrm{I}(1)$ & STATIONARY \\
\hline
\end{tabular}

Source: Authors' Computation, 2018.

Table 1 shows the unit root test and the order of integration of the data used for the variable. Unit root test is conducted to establish stationarity of data to avoid spurious regression result associated with time series data. The result shows that all the data series were stationary at first difference. 


\subsection{Descriptive Statistics}

Table 2. Statistical description of data

\begin{tabular}{lcccc}
\hline & LOGRGDP & LOGCPG & LOGSDM & LOGAGR \\
\hline Mean & 4.449360 & 3.817445 & 1.559543 & 3.774030 \\
\hline Median & 4.351205 & 3.834533 & 1.515953 & 3.672434 \\
\hline Maximum & 4.839000 & 3.968205 & 2.010909 & 4.235010 \\
\hline Minimum & 4.139226 & 3.607774 & 1.232553 & 3.362389 \\
\hline Std. Dev. & 0.238413 & 0.098899 & 0.232227 & 0.295364 \\
\hline Skewness & 0.393016 & -0.360503 & 0.380682 & 0.214797 \\
\hline Kurtosis & 1.696231 & 2.175645 & 2.066543 & 1.519301 \\
\hline & & & & \\
\hline Jarque-Bera & 3.573061 & 1.849092 & 2.236985 & 3.664574 \\
\hline Probability & 0.167540 & 0.396711 & 0.326772 & 0.160047 \\
\hline & & & \\
\hline Sum & 164.6263 & 141.2455 & 57.70310 & 139.6391 \\
\hline Sum Sq. Dev. & 2.046264 & 0.352119 & 1.941461 & 3.140644 \\
\hline & & & 37 \\
\hline Observations & 37 & 37 & \\
\hline
\end{tabular}

Source: Authors' Computation, 2018

The Jarque-Bera result confirms the normality of the distribution as they are all higher than 5\% level of significance. The standard deviation of all the variables are below the mean values. This signifies a lower spread which suggests that all the data set are clustered around the mean. The Kurtosis of the distribution indicates less extreme positive or negative economic situations may likely occur. That is with the present state and contribution of the economic resources, national development may not be at its best, which suggests stagnation. Therefore, the distribution is platykurtic since it is less than 3 . The skewness is greater than zero but not above 0.5 , which implies that the distribution is positively and approximately skewed but for CPG, the skewness is negatively and approximately skewed.

Table 3. Johansen Cointegration Test

Date: 08/25/18 Time: 09:42

Sample (adjusted): 19832017

Included observations: 35 after adjustments

Trend assumption: Linear deterministic trend

Series: LOGRGDP LOGCPG LOGSDM LOGAGR

Lags interval (in first differences): 1 to 1

Unrestricted Cointegration Rank Test (Trace)

\begin{tabular}{lcccc}
\hline \hline Hypothesized & & Trace & 0.05 & \\
No. of $\mathrm{CE}(\mathrm{s})$ & Eigenvalue & Statistic & Critical Value & Prob.** \\
\hline \hline
\end{tabular}




$\begin{array}{cllll}\text { None }{ }^{*} & 0.561616 & 53.78905 & 47.85613 & 0.0125 \\ \text { At most } 1 & 0.400248 & 24.92599 & 29.79707 & 0.1641 \\ \text { At most } 2 & 0.163375 & 7.032651 & 15.49471 & 0.5738 \\ \text { At most } 3 & 0.022302 & 0.789391 & 3.841466 & 0.3743\end{array}$

Trace test indicates 1 cointegrating eqn(s) at the 0.05 level

* denotes rejection of the hypothesis at the 0.05 level

***MacKinnon-Haug-Michelis (1999) p-values

Source: Authors' computation, 2018

The Johanson co-integration test on Table 2 reveals the existence of a long run relationship at 5 percent level of significance. This result implies that the long term sustainability of economic development is a function of proper investment in agriculture and other extractive industries identified in this study. Adequate investment in agriculture and solid minerals will mean long term economic development because these economic activities have the capacity to sustain it.

Table 4. Regression results

\begin{tabular}{|c|c|c|c|c|}
\hline Dependent Variable & & & & \\
\hline Method: Least Squa & & & & \\
\hline Date: $08 / 24 / 18 \quad \mathrm{~T}$ & & & & \\
\hline Sample: 19812017 & & & & \\
\hline Included observatior & & & & \\
\hline Variable & Coefficient & Std. Error & t-Statistic & Prob. \\
\hline LOGCPG & 0.060804 & 0.083402 & 0.729048 & 0.4711 \\
\hline LOGSDM & 0.117027 & 0.029609 & 3.952373 & 0.0004 \\
\hline LOGAGR & 0.740792 & 0.031909 & 23.21547 & 0.0000 \\
\hline $\mathrm{C}$ & 1.238963 & 0.252501 & 4.906766 & 0.0000 \\
\hline R-squared & 0.991147 & Mean dependent var & & 4.449360 \\
\hline Adjusted R-squared & 0.990342 & S.D. dependent var & & 0.238413 \\
\hline S.E. of regression & 0.023430 & Akaike info criterion & & -4.567776 \\
\hline Sum squared resid & 0.018116 & Schwarz criterion & & -4.393623 \\
\hline Log likelihood & 88.50386 & Hannan-Quinn criter. & & -4.506379 \\
\hline F-statistic & 1231.477 & Durbin-Watson stat & & 0.650021 \\
\hline Prob(F-statistic) & 0.000000 & & & \\
\hline
\end{tabular}

Source: Authors' Computation, 2018

The regression result on Table 4 shows a strong correlation (R) between the predictor variables and the response variable. The $\mathrm{R}$ value of $99.5 \%$ (square root of R-squared) indicates that the relationship between RGDP and crude petroleum and natural gas, solid minerals and agriculture is very high and strong. The R-Squared of $99.03 \%$ is the extent to which CPG, SDM and AGR can explain the variations in the RGDP. This value is also very high and suggests that only $0.97 \%$ (less than $1 \%$ ) of the changes in RGDP can be attributed to other factors not specified in the model. The Durbin-Watson is approximately 1 which indicates no cause for concern. However, the F-statistics is 
$0.000<0.05$, which means that the explanatory variables are collectively and statistically significant. Therefore the model is a good fit.

\subsection{Test of Hypotheses}

The study had earlier hypothesized that CPG, SDM and AGR do not significantly contribute to RGDP in Nigeria. In other words, the hypotheses are suggestions that investment in CPG, SDM and AGR may not yield returns that could impact significantly on national development. The outcome of the regression analysis shows that the contribution of

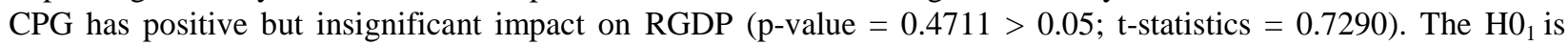
hereby accepted and the alternative which states otherwise rejected. This result is in discrepancy with the findings of Torben (2012) whose study revealed that petroleum resources and natural gas gave boost to Norwegian economy (GDP) by $20 \%$ from 1971 to 2007 . The findings of this study also disagreed with the previous studies of scholars like (Nwoba \& Abah, 2017; Usman, Ikemefuna \& Fatimah, 2015).

The regression result of this study equally indicates that SDM has a positive and significant impact on RGDP (p-value $=0.0004<0.05 ;$ t-statistics $=3.9524)$. Therefore, $\mathrm{HO}_{2}$ is rejected and the alternative accepted. The finding of this present study has conflicted with the findings of Jalloh (2013) but is in agreement with the results of the studies of (David, Noah \& Agbalajobi, 2016; Olofin \& Odeleye, 2016).

From the regression result on Table 4 above, AGR has a robust and significant positive impact on RGDP (p-value = $0.0000<0.05$; t-statistics $=23.2155$ ). In this case, $\mathrm{H}_{3}$ is rejected and the alternative accepted. This result does not agree with Eze (2017) who considered agricultural sector performance and economic growth in Nigeria from 1980-2014 and found that agricultural contribution to RGDP was though positive but insignificant. However, the result of this current study is in line with the findings of (Abula \& Mordecai, 2016; Olajide, et al., 2012; Younis, et al., 2012).

\subsection{Discussion on Findings}

A proper evaluation of the result of this study is pointing to the fact that agriculture in Nigeria if advanced could remedy the national economic problem in the country. From trend analysis with consideration to Figure 4, crude petroleum and natural gas was taking the lead in contributing to RGDP, but from 2005 agriculture overtook it and remained in a steady growth till date. The global economic meltdown that affected oil prices has nothing to do with agricultural produce. The regression result also confirms the fact that agriculture is impacting so much on economic development in the country. However, the contribution of solid mineral is also positive and significant. Though it has not been harnessed in full commercial quantity, but from the result the study has provided empirical evidence that SDM has the potential to improve the Nigerian economy. The policy implication of these findings is that there is an urgent need for the government to invest adequately in agricultural and extractive industry as a way of diversifying the economy and alleviating poverty in the country. In a more recent study by Omodero (2019), government expenditure on the key sectors of the economy including agricultural sector was found insignificant in poverty alleviation. Thus, economic diversification into agriculture and extractive industry requires a considerable investment which will give room for more export of domestic products and reduce unnecessary imports thereby improving the nation's balance of payment since it is a good source of foreign exchange.

Investment in agriculture will also enhance its contribution to national income. Studies have shown that agriculture contributes so much to national income. Specifically, about $28 \%$ of the national income of India emanates from agricultural sector. It is a sector that helps in national development through food supply and eradication of economic depression.

\section{Conclusion and Recommendations}

Based on the findings of this study, it will be necessary to draw a conclusion that economic diversification on agriculture and extractive industry is a step in the right direction. The result of the study has revealed that crude petroleum and natural gas are no longer contributing so much to economic development. This is the resultant effect of pipeline vandalism and other forms of oil theft the country has been going through, followed by the global crash in oil prices. Secondly, the inability of the nation to manage the exploration activities which must involve multinational companies that are foreigners also does not guarantee national development, as the primary aim of these foreigners remains to repatriate funds to their home country for development.

The study therefore, recommends that investment in agriculture should be encouraged by the government through robust budget for agricultural expansion and implementation monitoring. There should be easy access to credit facilities to encourage upcoming agricultural firms to expand and contribute to national development instead of continuing as underground businesses and conceal their incomes (Omodero, 2019). The extraction of solid minerals 
should also be encouraged to be in a full commercial scale to create more employment opportunities and be a good source of income to the nation. Finally, the government of Nigeria should endeavor to have total control of the exploration of crude petroleum and natural gas for its maximum benefit to accrue to the country.

This study suffered some drawbacks which include lack of sufficient data and empirical studies combining all the variables in one study. However, upcoming researchers are encouraged to leverage on this gap in order to enrich empirical literatures in this area of research.

\section{Acknowledgement}

The authors are obliged to the editors and anonymous reviewers of Research in World Economy (RWE) for their suggestions that improved the quality of this paper. This paper was initially presented at the $8^{\text {th }}$ Annual International Conference of Accounting and Finance Research Association (AFRA), held at the University of Calabar, Cross River State, Nigeria on the $4^{\text {th }}-7^{\text {th }}$ November 2018, prior to its completion in January 2020. The authors thank the AFRA conference participants for their invaluable contributions that boosted the credibility of this paper.

\section{References}

Abellanosa, A. L., \& Pava, H. M. (1987). Introduction to Crop Science. Central Mindanao University, Musuan, Bukidnon: Publications Office, p. 238.

Abula, M., \& Mordecai, D. B. (2016). The impact of agricultural output on economic development in Nigeria (1986-2014). Archives of Current Research International, 4(1), 1-10.

Afredo, M., \& Vicente, S. (2010). Investment and intangible: evidence from Banks. Working Paper, Banco de Espana Eurosistema, Universidad De Zaragoza, pp. 1-37.

Business Dictionary. (2018). Extractive Industry. Retrieved August 25, from www.businessdictionary.com/Definition/extractive-industry.html

David, O. O., Noah, O. A., \& Agbalajobi, S. A. (2016). An empirical analysis of the contribution Of Mining sector to economic development in Nigeria. Khazar Journal of Humanities and Social Sciences, 19(1), 88-106.

Eklund, J. E. (2013). Theories of investment: a theoretical review with empirical applications. Working paper from Swedish Entrepreneurship Forum, pp. 1-20.

Eze, O. M. (2017). Agriculture sector performance and Nigeria's economic growth. Asian Journal of Agricultural Extention, Economics and Sociology, 15(1), 1-13.

Godfray, H. C. J., Beddington, J. R., Crute, I. R., Haddad, L., Lawrence, D., Muir, J. F., ... Toulmin, C. (2010). Food security: the challenge of feeding 9 Billion People. Science, 327(5967), 812-818.

Himley, M. (2015). Social conflict, economic development and extractive industry: evidence from South America. Conservation and Society Interdisciplinary Journal, 13(3), 321-322.

International Accounting Standard (IAS) 41. Agriculture.

International Financial Reporting Standard (IFRS) 6. Exploration for and Evaluation (E\&E) of Mineral Resources.

Jalloh, M. (2013). Natural resources endowment and economic growth: The West African Experience. Journal of Natural Resources and Development (JNRD), 3, 66-84.

Jorgenson, D. W., \& Stephenson, J. A. (1967). Investment behavior in U.S. manufacturing 1947-1960. Econometrica, 35.

Kniivilä, M. (2004). Industrial development and economic growth: Implications for poverty Reduction and income Inequality. Industrial Development for the 21st Century, Pellervo. Economic Research Institute, Helsinki, Finland, 295-331.

Lawrence, A., \& Salako, M. A. (2015). Agriculture, economic growth and development nexus: VAR Variance decomposition evidence from Nigeria. International Journal of Economics, Commerce and Management, 3(6), 460-478.

Love, I., \& Zicchino, L. (2006). Financial development and dynamic investment behavior: Evidence from panel VAR. The Quarterly Review of Economics and Finance, 46, 190-120.

Mahendra, K. (2018). Human development: meaning, objectives and components. Retrieved from http://www.economicsdiscussion.net/human-development/human-development-meaning-objectives-and-compo nents/11754 
Manji, F. (2014). Development or amputation? The role of extractive industries. United Nations Economic Commissions for Africa. Retrieved August 25, 2018, from http://www.aljazeera

My Agriculture Information Bank. (2018). What is Agriculture?. Retrieved from www.agriinfo.in/default.asp

Olajide, O. T., Akinlabi, B. H., \& Tijani, A. A. (2012). Agriculture resources and economic growth in Nigeria. European Scientific Journal, 8(22), 103-115.

Olofin, O. P., \& Odeleye, A. T. (2016). Solid minerals, government effectiveness and poverty Reduction in Nigeria. Retrieved August 28, 2018, from jhss-khazar.org/wp-content/uploads/2016/

Omodero, C. O. (2019). Government sectoral expenditure and poverty alleviation in Nigeria. Research in World Economy, 10(1), 80-90. https://doi.org/10.5430/rwe.v10n1p80

Omodero, C. O. (2019). The financial and economic implications of underground economy: The Nigerian Perspective. Academic Journal of Interdisciplinary Studies, $8(2), \quad$ 155-167. https://doi.org/10.2478/ajis-2019-0027

Omorogiuwa, O., Zivkovic, J., \& Ademoh, F. (2014). The role of agriculture in the economic Development of Nigeria. European Scientific Journal, 10(4), 133-147.

Pragyandeepa. (2018). Agriculture in the economic development of a country. Retrieved August 25, from http://www.economicsdiscussion.net/economic-development/role-of-agriculture-in-the-economic-developmentof-a-country/4652

Richardson, G. B. (1960). Information and investment: a study in the working of the competitive Economy. Oxford and Clarendon Press.

Rimando, T. J. (2004). Crop Science 1: Fundamentals of Crop Science. U.P Los Banos: University Publications office. P.I.

Rubenstein, J. M. (2003). The Cultural Landscape: An introduction to Human Geography (7th ed.). Upper Saddle River, NJ: Pearson Education, Inc. p. 496.

Sahoo, K., \& Sethi, N. (2012). Investigating the impact of agriculture and industrial sector on Economic growth in India. OIDA International Journal of Sustainable Development, 5(5), 11-22.

Scheibl, F., \& Wood, A. (2004). Investment sequencing in the Brick Industry: an application of Grounded theory. Working paper, pp. 1-24.

Smith, A. (1776). An Inquiry into the nature and causes of the Wealth of Nations (5th ed.). London: Methuen \& Co. 1904.

SØrensen, P. B., \& Whitta-Jacobsen, H. J. (2010). Introducing Advanced Macroeconomics, Growth And Business Cycles (2nd ed.). McGraw-Hill Higher Education, New York.

Souza, D., \& Paulo, A. J. (2014). Growth complementarity between Agriculture and Industry: Evidence from a panel of developing countries. Working paper, pp. 1-37.

Tiffen, M., \& Mortimore, M. (1990). Theory and practice in plantation/agriculture: an economic Review. London, ODI.

Todaro, M. P., \& Smith, S. C. (2003). Economic development (8th ed.). Singapore: Pearson Education.

Torben, K. M. (2012). The Economic Impact of Natural Resources. Part of Research Project at the Centre of Equality, Social Organisation, and Performance (ESOP), Department of Economics, University of Oslo.

Vermeulen, S., \& Cotula, L. (2010). Making the most of agriculture investment: a survey of Business models that provide opportunities for small holders, pp. 1-97. IIED/FAO/IFAD/SDC, London/Rome/Bern.

Verspagen, B. (2000). Growth and structural change: trends, patterns and policy options. Paper Prepared for the conference on Wachstums- und Innovationspolitik in Deutschland und Europa. Problem, Reformoptionen und strategic-zu Beginn des 21. Jahrhunderts, Potsdam, April 14, 2000.

Younis, A. A., Biaban, N. R., \& Burhan, A. M. (2015). Sharing the agriculture and industrial sectors in the economic growth of Iraq: an Ordinary Least Squares (OLS) application. Journal of Emerging Trends in Economics and Management Sciences (JETEMS), 6(5), 340-353. 